\title{
Malkom Khan's Thoughts on Modernization of Political Culture in Iran
}

\author{
Kamyab Shahriari (Corresponding Author) \\ Department of Politics and Government, Faculty of Human Ecology, University Putra \\ Malaysia (UPM) \\ Serdang, Selangor, Malaysia \\ E-mail: shahriarikamyab@gmail.com
}

Ku Hasnita Ku Samsu

Department of Politics and Government, Faculty of Human Ecology, University Putra Malaysia (UPM)

Serdang, Selangor, Malaysia

E-mail: hasnita@upm.edu.my

Received: August 18, 2014 Accepted: August 25, 2014 Published: September 21, 2014

doi:10.5296/ijch.v1i2.6153 URL: http://dx.doi.org/10.5296/ijch.v1i2.6153

\begin{abstract}
Malkom Khan with his goal in this period of establishing constitutional monarchy gave priority to political culture and criticized the dominant traditional political culture of society. In this period, in addition to paying attention to modernization of political structures and creation of new, modern structures and institutions Malkom Khan also emphasized cultural aspects of society and especially the political culture, by criticizing traditional political culture and attempted to modernize political culture of society. Research result shows that Malkom Khan understood well that the creation of a modern and new political structure must be accompanied by modernization of political culture if the new established structures are to operate effectively and for this purpose he proposed participant political culture instead of subject political culture.
\end{abstract}

Keywords: Iran, Malkom Khan, political culture, constitution 


\section{Introduction}

According to Almond and Powell (1966) Political Culture is the pattern of individual attitudes and orientation towards politics among the members of a political system. In studying any political system, therefore: It needs to know its underlying propensities as well as its actual performance over a given period of time. These propensities or psychological dimension of the political system can be referred as political culture. It consists of attitudes, beliefs, values, and skills which are current in an entire population, as well as those special propensities and patterns, which may be found within separate parts of that population (p. 23). Also, Sidney Verba considers the political culture of a society as "a set of empirical beliefs, expressive symbols, and values which define the situation in which political action takes place" (Verba, 1965, p. 513). And there is a close circle of relationship between culture and structure. Malkom Khan, with his goal in this period of establishing constitutional monarchy, gave priority to political culture and criticized the dominant traditional political culture of society. In this period, in addition to paying attention to modernization of political structures and creation of new, modern structures and institutions Malkom Khan also emphasized cultural aspects of society and especially the political culture, by criticizing traditional political culture and attempted to modernize political culture of society. Therefore, this article attempts to examine Malkom Khan's thoughts on political culture.

\section{Criticizing and Desecrating the Political Authority and King's Authority}

Malkom Khan stepped up his criticizing of the traditional political culture in keeping with the political aim of that period, which was the establishment of a parliamentary constitutional government through mobilizing the people against the Qajars. While in his first period of activity, Malkom Khan wrote some treatises and reports, in the second period, he chose a suitable instrument to achieve his aim and published extensively in the Ghanoon newspaper. It was during this period that he criticized all aspects of absolute political culture, including the king. Meanwhile, Malkom Khan knew that the king was considered a deeply revered man in the Iranian traditional political culture and people believed that the appalling behavior of agents and government officials, and their oppression, were the reasons for the hardship in their lives.

It was this belief that prevented him from criticizing the king hastily. But when he became sure that the people welcomed the views in the Ghanoon newspaper, he started openly criticizing Naser al-Din Shah. For example, in the $8^{\text {th }}$ issue of the Ghanoon newspaper, he published an objection by a newspaper critic in relation to his political conflict with the King, to which he understandably did not respond. He chose to entrust the readers to form their own conclusions on this issue. In criticizing the dominant political culture in society, Malkom Khan believed that: people always criticized ministers and commended the king. But ministers do not have any authority and they are selected by the king and thus the onus of responsibility has to necessarily fall on him. "There was not much point in criticizing Amin-al Soltan, the prime minister because even if he were to be fired or to die, the King may well install an even more incompetent successor to him. Basically, the King did not like competent men and made sure that the ministries and governmental machinery were in a state 
of disarray, presumably to reduce chances of them being a threat to his position" (Malkom Khan, 1976a). In fact, it was through such criticisms that Malkom Khan presented a real picture of the government structure of that period. It was on the basis of all this that he was able to establish his credibility to comment on the drawbacks of despotism openly.

According to Malkom Khan, the method of governance in Iran was to keep the people as poor, ignorant and miserable as much as possible so that they would tolerate any oppression, without having the power to protest. He had revealed that this deep realization of the evils of despotism was what drove him to disagree with the existing norms of the Iranian political culture. The people of Iran hoped that by opposing this form of political culture, the king would solve all of their problems and disorders. Malkom Khan believed that: "the people of Iran themselves, should think and decide about reforming the disorders" (Malkom Khan, 1976a).

\section{Political Culture of Law Demanding}

By criticizing this traditional political culture which believed the establishments of justice as nothing but a gift of the king, and concentrating all efforts to encourage the king to actually practice an equitable system of justice, Malkom Khan was looking for an enduring solution to the government's absolutism toward the people. Then he proposed that the people should demand for law as the norm of modern political culture. He believed that "the aim of law was to establish a government based on the decree of law in a way that the government's ministries and positions be in the hands of competent and qualified people" (Malkom Khan, 1976c). It was by such criticisms of autocracy and absolute power in despotic government that Malkom Khan sought to negate this government and replace it with a parliamentary constitutional monarchy. Basically, in a traditional political culture, the king was credited as the highest authority and had absolute power. That was a power which was sanctified because of its absoluteness and which expected unquestioning obedience of the people. By accepting absolute power in the traditional political culture, Iranians had in fact accepted to obey such power unconditionally. It was during this period that Malkom Khan attacked more forcefully than before, the high ranking officials of the Iranian government who, as he put it, did not know of anything except destroying and ruining Iran. In a reply to the question; "What are the characteristics of these men who continue their wrongdoings without a second thought", Malkom said: Firstly, they do not feel ashamed of have any feelings of disgrace at all; secondly, they are truly the enemies of knowledge and promoters of impudence; thirdly, they are misguided as they see themselves to be more elevated and better than other people" (Kazemi, 2002).

Malkom Khan knew those politicians did not have any goal except making personal profit and being self-seeking. He was aware of the fact that these men just wanted to achieve their personal ambitions by manipulating the king's powers through flattery. Malkom Khan wrote in the Ghanoon newspaper, addressing the ministers: "You say the king's opinion is elixir. So, if the opinion of Shah Soltan Hossein was indeed elixir, why has he lost the government and monarchy of Iran so disgracefully".(Malkom Khan, 1976h). In Malkom Khan's opinion, people were dependent on politicians in all fields. The political culture did not require these 
officials to act responsibly rather they acted with utter impunity for the greater part. Thus, for this reason, Malkom Khan believed that: the expediency of the monarchy system had left Iranians in distress as they had no option but to meekly obey the government's officials. Even the prime minister paid no heed to addressing the issues confronting the people and the country, so much so that "Iran's cities are more ruined than the cemeteries of foreign countries and Iranian merchants do not have investments as the Jewish do in the villages of France or England" (Malkom Khan, 1976g). He viewed this attitude of the government officials from the cultural and social perspective and believed that the officials of a despotic government would be especially careful to ensure that no Iranian should know about unity, justice, law and humanity at all, because "it is required for the government system that Iranians do not have any duty except obeying this despotic government system" (Asil, 2002a).

\section{Criticizing the Culture of Fatalism and Introducing Secularization of Political Culture}

Malkom Khan, who raised his political goal to the establishment of a parliamentary constitutional government, had to motivate people towards political confrontation with the autocratic Qajar government to accomplish that goal. As a result of the traditional political culture, Iranians were apathetic towards despotism because they were oppressed and in fear. However, Malkom Khan in his treatises and writings invited them to confront the government, which meant a different orientation altogether in the political culture of Iranians. With such a goal in mind, however, Malkom Khan was faced with a traditional political culture where people did not harbor any conscious political motivation against the government to change the political situation. Iranians who only regarded themselves as peasants and 'flocks' (raiyyat va rameh) who had been dependent on the government and conditioned by such a government for thousands of years, did not believe that they could bring about any change at all. Such belief had caused Iranian political culture to be intensely conservative, at least from the Ghaznavids era.

Malkom Khan, who was always looking to the future for change and development, had generally taken a non-conservative attitude in the political field and in his writings. Meanwhile, he tried persistently, through his writings in the Ghanoon to reject this form of traditional political culture which implied that people were not effective in introducing norms of modern political culture that contended that people could play an effective role in changing a dominant political-social situation in their society. He believed that "Human superiority over animals is due to the reason that animals cannot develop and improve, but humans can develop or decline to an infinite extent. Such human progress and regression are totally dependent on his free will, effort and attempts. Whenever a human decreases his level of humanity (Adamiyyat) by his evil deeds, he declines from the position of humanity and when he promotes his level of humanity by his noble deeds and efforts, he raises himself in the realm of humanity (Malkom Khan, 1976i). Through constant and deep criticism of the oppression caused by despotism, Malkom Khan was of the opinion that usurpers of the nation's rights had conditioned the people to tolerate any kind of abject condition and misery in a way that these down-trodden people thought it was impossible to have a better life. So, 
initially, this wrong perception and belief had to be eliminated. According to him, "people can be empowered to remove all of these problems and troubles and the nation can be powerful - but only if the people were united" (Asil, 2002c). While Malkom Khan introduced a new political culture to people generally, he also specifically presented some elements of modern political culture to Iranians and urged them to act according to these elements. For example, he urged people to to engage in civil disobedience and in the $12^{\text {th }}$ edition of the Ghanoon newspaper on behalf of a clergyman he encouraged people not to pay tax to the government because it was without any legal basis.

Of course, those who were unwilling or incapable of accepting that they really could have any effect in altering the dominant political situation were unconcerned about this situation and stayed on the sidelines, viewing politics and politicians on the whole, with distrust. Another important factor was the element of fear among the people which prevented them from neither acting against a despotic government nor getting involved in politics. It may be argued that Malkom Khan reserved his harshest criticisms for people's political indifference, more than anything else. For example, when he reprimanded government officials' oppression toward the people, he went on to say: "Government officials of Iran, here I do not have anything to say to you because you have sold your dignity, humanity and sense of fairness for money. I am talking with those men who are unconcerned and do not know that this oppression which they validate and strengthen by their stupidity and silence will be their destiny tomorrow" (Asil, 2002d, p. 136).

The separation of people from government in a despotic government and the people's indifference and distrust of it influences their political-social behavior in a way that cause people to be unconcerned and distrusting toward each other as well. This matter has had a determinative effect on Iranians' political behavior, so Malkom Khan felt he should confront this feature of traditional culture in order to encourage people to become united. He created the slogan for the Ghanoon as "Unity, Justice and Progress". He elevated "Justice" together with the other two important elements of Unity and Progress, as most prominent goals for the new political system within Iranians' traditional political culture, but with a modern meaning. To create and strengthen unity among the people, Malkom Khan attempted, from a conscious and progressive stance, to criticize and negate people's distrust, indifference and apathy toward each other. The treatise "principles of humanity" (osoole adamiyyat) is one of his most important works in this field.

\section{Introducing the Principles of Humanity (Osoole Adamiyyat) as a Modern Political Culture}

This treatise which generally introduced a modern political culture to Iranians began with this description from humanity (Adamiyyat) that: "Whenever a human promotes his level of Insaniyyat higher than his previous position, then he enters into the realm of humanity"(Adamiyyat)" (Asil, 2002e). Malkom Khan believed that progress and perfectionism form the base of the ideology of humanity. Then he introduced seven principles of ideology of humanity for accomplishing it and he enumerated some viewpoints which explain each of these tasks in detail. Here, he emphasized the principles and responsibilities 
which were hitherto unknown in Iranian political culture. For example, on the principle of removal of oppression, he presented a progressive and modern political perception of confronting oppression. Although eliminating and denouncing oppression, whether of kings toward the people or of people towards each other, has been always emphasized in traditional political culture during past centuries, it was done purely from the moral aspect.

According to Malkom Khan, it is very important that man does not allow people to oppress each other too. This was because in his opinion, "Manliness means unity with everyone who is being oppressed and fighting with every oppressor (Rahimi, 2006). Malkom Khan, instead of denouncing oppression in the ambit of individual traditional morals, urges struggle against injustice, because in his opinion, it was the basis of order in the world. He emphasized that: "When someone treats you cruelly, you are free to forgive the oppressor. But when someone else is oppressed, you cannot forgive it at all and should help the oppressed in removing that oppression and retaliating. You should understand that if someone is oppressed in a country, surely other people in that land will be oppressed too. The oppression toward one man is like oppression toward all human beings" (Asil, 2002e, p. 330).

Malkom Khan applied such understanding to awaken people's awareness about public benefits instead of mere attention to personal benefits, in order to promote people's alliance and trust in each other. He indicated many times that this feature of traditional culture, in which people sought personal security in isolation, avoidance and just thinking about themselves, was the consequence of a political situation in which people did not have any control over their own responsibility. By criticizing this feature, Malkom Khan invited people to unite against oppression and understand unity as the element of establishing real security for people. While Malkom Khan introduced unity to Iranians in its political meaning, as an element of modern political culture, he also accompanied it with a new description of the principles of traditional political culture, so he gave it a familiar, palatable form.

In the treatise, Principles of Humanity"(osoole Adamiyyat) he said: "Unity is the castle of justice and shelter of life. Everyone who abandons human unity is like a man who destroys the castle of the city and invites the enemy's army into his house" (Mojtahedi, 2000). While in traditional political culture, justice is completely in the hands of the king, Malkom assigned it to the unity of the people. His significant action in introducing a modern political culture to Iranians was by the compilation of "Ideology of Humanity" (Marame Adamiyyat). His ideology of humanity is a human-oriented ideology which did not have any place in Iran's theocratic culture. By considering the role and standing of religion in Iran's traditional culture, Malkom Khan attempted to promote his secular human-oriented ideology without direct confrontation with the religious traditional culture. He promoted this secular outlook and thought, that the human is the determinative element for his situation. In other words, it is the human himself who determines his destiny. In Malkom Khan's opinion, God has created man in the position of insan (human being). Then, he declared that reaching the position of humanity (Adamiyyat) is only possible by the action of man himself. He knew the instrument required for this was gaining knowledge and realization of the unity of humanity. He believed that: "When a man advances in the position of humanity, he becomes sublime both as a man and as a member of society all prophets wanted such sublimity for humans" (Malkom Khan, 
1976b).

Malkom Khan's emphasis on unity of humanity as the condition for sublimity is important because in his opinion, man's sublimity is impossible in personal and individually oriented work. This outlook of Malkom Khan, which contradicts the agnostic understanding, gives a political-social context for sublimity of humans, and is the basis of his ideology of humanity. Malkom Khan stated in this regard that: God has always been able to fill the world with prosperity and happiness, but according to expediency, human happiness is linked to his own effort. So, until a man does try to elevate himself by his efforts, he will not reach ideal levels of prosperity and happiness" (Asil, 2002b).

\section{Participant Political Culture as a Modern Element of Political Culture}

Malkom Khan presented his most complete and comprehensive description of the ideology of humanity (marame adamiyyat) in the treatise "The principles of humanity" (osoole Adamiyyat) which is considered as the doctrine of the League of Humanity (majame adamiyyat) during this period of theorizing and political activity, Malkom Khan emphasized greatly on the people's participation in determining their political destiny and as people's political participation requires some institutions to organize and lead people's political activities, he founded the League of Humanity as a highly regarded organization, both inside and outside of Iran, and compiled the ideology of humanity in accord with the historical realities. As mentioned before, Malkom Khan proposed a plan to establish a national consultative assembly, with its representatives elected by the people through elections. It indicated that Malkom Khan attempted to change the political culture of Iranian society and also make people familiar with participant political culture which was, until then, unknown in Iranian culture.

In an effort to organize the masses, Malkom Khan said: People won't be united except by organizing some associations. Prosperity of humanity depends on the League of Humanity, and the prosperity and continuity of the League of Humanity depends on the knowledge and devotion of its members (Malkom Kan, 1976). It is also noteworthy that Malkom Khan disagreed with taghiyyah or prevarication or denying his belief, something that was deeply ingrained in Iranian traditional political culture. He asked the followers of marame adamiyyat not to deny their beliefs, because he believed that: "It is necessary to be cautious, but negating adamyyat (humanity) and our beliefs is in conflict with God's commandments. God has created all of us as human (Adam) and so why should we be afraid of expressing our beliefs? (Malkom Khan, 1976d). In that period of his life when he presented the idea of a constitutional government, Malkom Khan demanded the people's active fight against despotism. He posed and criticized extensively the most offensive features of traditional political culture in the Ghanoon newspaper. In severe criticism of Iranians, Malkom Khan said: "The big defect of Iranians is that they do not believe Iran is their land and think God had created the land and people just for the use and enjoyment of kings and rulers. Thus, they condescended to any oppression and mistreatment and always bowed in front of cruel men, exclaiming: 'All we have - our possessions, family and our life - belongs to you" (Malkom Khan, 1976e). But in Malkom's opinion, as people's obedience of despotism and the showing 
of their loyalty towards it is accompanied with the expectation of personal benefits, this leads to collaboration with those in government who only think of exploiting them. It is because of this, that in criticism of their misdeeds, Malkom Khan wrote: The situation of Iran is not bad and disorganized just because of government officials' degeneration; rather government officials and sycophants have instilled these simple-minded people with the idea that serving this government is legitimate and it is obligatory for the nation to obey it. Because of this wrong belief, some sycophants and opportunists have had their grip on this government and do not neglect any opportunity to oppress the people (Malkom Khan, 1976f).

Generally, it can be said that as Malkom Khan's goal in this period was inciting the people against the Qajar dynasty, the first step would be to create doubt in the minds of the people about the legitimacy of the government and the absolutist political culture. Malkom built his case against toward the traditional political culture in two ways: as the Qajar government was relying on traditional legitimacy, Malkom promoted legal and rational legitimacy. In this aspect, he persisted relentlessly in advocating his view of modernizing political culture. He dealt specifically with the government being centered around one person who was made out to be the 'shadow of God' and its detrimental consequences. He then presented a law-based form of government in favor of it. Also, with his mararame adamiya (Ideology of Humanity), Malkom Khan introduced a human-oriented political culture to Iranians which was practically unheard of, in Iranian culture. In the first period of his life, both as a theoretician and as a political activist, Malkom Khan referred to despotism as a lawless government and promoted a political culture which emphasized state-building based on legalizing government. But in the next period of his life, he proposed a political culture based on nation-building and democracy. Meanwhile, he tried to give a familiar face to this modern political culture by using some of the traditional beliefs and giving a religious flavour to the principles of this new political culture. So, he attempted through the Ghanoon to provide some evidence from the Quran and hadith to justify from the religious standpoint, the seven principles of the Ideology of Humanity and show that they were rooted in Islam teachings.

Malkom faced a traditional political culture which, by its nature, was the result of integration between religion and government. Thus, the government's political legitimacy in Iran also had the underpinnings of religious legitimacy. Meanwhile, since the end of the Safavid monarchy, the creation of a schism between the monarchy system and clerical institution led many members of the clergy to relinquish legitimization of the government, and posed the issue of Imam Zaman's (hidden imam) lieutenancy and ruling based on imamat. This group of clergy first divided power between themselves and the dominant political power and then proposed their ideal form of government, which was a religious government headed by the hidden imam (Imam Zaman) at the beginning of the Qajar dynasty. Of course, the Shiite clergy used all religious values of the traditional political culture to legitimize this ideal government.

Based on this feature of traditional political culture which was the result of unity between religion and government, Malkom Khan adopted a dual approach to undermine the political legitimacy of Qajar. In one approach, he negated religious justifications for government legitimacy and religious obligation to obey the government. By such an attitude, he attempted 
to both incite people to confront the Qajars by criticizing traditional political culture and also to widen the gap between the clergy group and the government.

By highlighting the incorrectness of legitimizing the government through the strategy of unifying religion and government, Malkom Khan tried to lead a progressive class of clergymen and incite them to remove the legitimacy of the government by presenting a new interpretation of the people's religious beliefs. Although in this period of his activity, Malkom Khan proposed his ideas about parliamentary constitutional government with due regard to Iran's unique situation, and created a modern political culture that was generally based on the Ideology of Humanity (Marame Adamiyyat) especially in the Ghanoon newspaper, he basicall attempted to incite people to confront the Qajar government. He criticized the people's indifference and political-social apathy in several editions of the Ghanoon. By justifying and using different tactics, he attempted to get rid of this apathy and indifferent attitude among Iranians and invited them to participate in changing the political situation of society. For this purpose, he sometimes followed some religious features of traditional culture and by playing on people's beliefs, invited them to participate in dynamic political action. Nevertheless, the basis of his effort in removing people's apathy and indifference was his intimate knowledge of the Iranians' individual and collective psyche.

\section{Conclusion}

Malkom Khan, with his goal in this period of establishing constitutional monarchy, gave priority to political culture and criticized the dominant traditional political culture of society. In this period, in addition to paying attention to modernization of political structures and creation of new, modern structures and institutions Malkom Khan also emphasized cultural aspects of society and especially the political culture, by criticizing traditional political culture and attempted to modernize political culture of society.

He understood well that the creation of a modern and new political structure must be accompanied by modernization of political culture if the new established structures are to operate effectively. He also criticized the political culture of the despotic government, including the monarch. Since in a despotic government the relationship between the monarch and the people is authoritarian, therefore, the dominant political culture of Iranian society was subject political culture. Malkom Khan, by criticizing the passive culture of the people, urged the people to participate actively and claim the right of determining their own destiny. And with the proposal of a national consultative assembly (majlise shoraye melli) with representatives elected by the people, Malkom Khan was trying to change the subject-political culture to participant -political culture.

\section{References}

Almond, G., \& Powell, G. B. (1966). Comparative Politics: A Developmental Approach: Boston Little Brown and Co.

Asil, H. (Ed.). (2002a). Resaleha ye Malkom Khan. Resaleye Osule Mazhabe Divanian Collected Works. Tehran: Ney.

Asil, H. (Ed.). (2002b). Resaleha ye Malkom Khan. Resale ye Meftah. Collected Works. 


\section{Macrothink \\ International Journal of Culture and History \\ ISSN 2332-5518 \\ 2014, Vol. 1, No. 2}

Tehran: Ney.

Asil, H. (Ed.). (2002c). Resaleha ye Malkom Khan Nazem al -Dowleh. Resaleye Tofighe Amanat Collected Works. Tehran.

Asil, H. (Ed.). (2002d). Resaleha ye Malkom Khan. Resaleye Nedaye Edalat Collected Works. Tehran: Ney.

Asil, H. (Ed.). (2002e). Resalehaye Malkom Khan. Resaleh ye Osoole Adamiyyat. Collected Works. Tehran: Ney.

Kazemi, A. (2002). Bohrane Nogaraei Va Farhange Siasi Dar Irane Moaser. Tehran: Ghomes.

Malkom Kan, M. (1976). Rouznameh ye Ghanoon (No. 31) Collected Works (H. Nateq Ed.). Tehran: Amir Kabir.

Malkom Khan, M. (1976a). Rouznameh ye Ghanoon (No. 8) Collected Works (H. Nateq Ed.). Tehran: Amir Kabir.

Malkom Khan, M. (1976b). Rouznameh ye Ghanoon (No. 21) Collected Works (H. Nateq Ed.). Tehran: Amir Kabir.

Malkom Khan, M. (1976c). Rouznameh ye Ghanoon (No. 5) Collected Works (H. Nateq Ed.). Tehran: Amir Kabir.

Malkom Khan, M. (1976d). Rouznameh ye Ghanoon (No. 32) Collected Works (H. Nateq Ed.). Tehran: Amir Kabir.

Malkom Khan, M. (1976e). Rouznameh ye Ghanoon (No. 17) Collected Works (H. Nateq Ed.). Tehran: Amir Kabir.

Malkom Khan, M. (1976f). Rouznameh ye Ghanoon (No. 20) Collected Works (H. Nateq Ed.). Tehran: Amir Kabir.

Malkom Khan, M. (1976g). Rouznameh ye Ghanoon (No.14) Collected Works (H. Nateq Ed.). Tehran: Amir Kabir.

Malkom Khan, M. (1976h). Rouznameh ye Ghanoon (No. 16) Collected Works (H. Nateq Ed.). Tehran: Amir Kabir.

Malkom Khan, M. (1976i). Rouznameh ye Ghanoon. (No.19) Collected Works (H. Nateq Ed.). Tehran: Amir Kabir.

Mojtahedi, K. (2000). Ashnae ye Iranian ba Andishehaye Modern e- Gharb Tehran: Hermes.

Rahimi, H. (2006). Farhange Siasi az negahe roshanfekrane iran. Tehran: Negahe Moaser.

Verba, S. (1965). Political Culture and Political Development. Princeton: Princeton Universty Press. 


\section{Copyright Disclaimer}

Copyright for this article is retained by the author(s), with first publication rights granted to the journal.

This is an open-access article distributed under the terms and conditions of the Creative Commons Attribution license (http://creativecommons.org/licenses/by/3.0/). 